\title{
Plantain (Plantago lanceolata) - a potential pasture species
}

\author{
A.V. STEWART \\ Pyne Gould Guinness Ltd, PO Box 3100, Christchurch
}

\begin{abstract}
Plantago lanceolata L. is a herb species with a broad distribution in grasslands throughout the temperate world. The leaf is highly palatable to grazing animals, providing a mineral- rich forage. The species is rapid to establish, grows on a wide range of agricultural soils and is tolerant of drought and of many common diseases and pests. Two productive upright cultivars of plantain have been bred, Grasslands Lancelot and the more erect winter active Ceres Tonic. Plantain contains a range of biologically active compounds, often in large quantities. The antimicrobial compounds present can inhibit rumen fermentation and change the volatile fatty acid composition of the rumen. These changes have potential to affect bloat, animal performance and milk composition. The performance of animals grazing plantain has varied from excellent in mixed pastures to poor on nitrogen-fertilised pure swards. Animals grazing plantain have been observed to have a reduced incidence of scouring and dags in some trials, but despite a mild anthelmintic effect detected in the laboratory, field trials have failed to detect any significant reduction in worm burdens. The most likely use of plantain on farms is as a component of mixed pasture swards. Its contribution is likely to be greatest where grass growth is less vigorous and where there are gaps in the sward. These conditions are likely to be found in low fertility dryland pastures. It is unlikely to be the dominant species and could be expected to contribute less than $20 \%$ of the sward, except where the grass or legume growth is poor.
\end{abstract}

Keywords: perennial forage herbs, Plantago lanceolata, plantain

\section{Introduction}

Plantago lanceolata L., known as narrow leaf plantain or ribgrass, occurs naturally in many pastures and has had a long history of use as a minor forage plant in Europe (Foster 1988). However, modern agriculture has not valued the perennial herb component of pastures.
In the last few years, however, the perennial herb chicory (Cichorium intybus L.) has been shown to be highly productive and capable of giving excellent animal performance. This has opened up the possibility that other perennial herbs could also be valuable as pasture components.

The ready acceptance of Plantago lanceolata by livestock and its widespread and successful adaptation to grassland communities throughout the temperate world makes it an obvious candidate for further study. The development of a productive cultivar of Plantago lanceolata was recognised by Dr W. Rumball (pers. comm.) as a prerequisite to using this species in New Zealand agriculture and Grasslands Lancelot was released. The release of a second cultivars, Ceres Tonic, now provides good opportunity to research this species and utilise any benefits it can provide.

\section{The cultivars Grasslands Lancelot and Ceres Tonic}

The cultivar Grasslands Lancelot was selected by AgResearch Grasslands from collections from productive North Island pastures. This cultivar was selected for bushy growth habit and the ability to tiller strongly under close sheep grazing (W. Rumball pers. comm.).

The cultivar Ceres Tonic was selected by the author from germplasm believed to have originated from northern Portugal, a region with warmer winters than most of New Zealand. This cultivar was selected for a very erect habit and very large leaves. Tonic remains erect under a wide range of conditions while Lancelot has the plasticity to become prostrate under close grazing.

The two cultivars are quite different in morphology and seasonal productivity, both from one another and from the common flatweed type as follows:

\begin{tabular}{|c|c|c|c|}
\hline & Grasslands & Ceres & Common \\
\hline & Lancelot & Tonic & flatweed type \\
\hline $\begin{array}{l}\text { rowth habit } \\
\text { eaf size }\end{array}$ & $\begin{array}{l}\text { semi-erect } \\
\text { med-large }\end{array}$ & $\begin{array}{l}\text { very-erect } \\
\text { verv large }\end{array}$ & $\begin{array}{l}\text { prostrate } \\
\text { small-med }\end{array}$ \\
\hline $\begin{array}{l}\text { eaf size } \\
\text { iller number }\end{array}$ & high & medium & med-high \\
\hline & low & high & very low \\
\hline mmer gro & high & high & low \\
\hline
\end{tabular}




\section{Establishment of plantain}

Plantain emergence is very rapid approaching that of perennial ryegrass (Blom 1978) and faster from autumn sowing than many common grasses (Table 1). Despite this however, the proportion establishing can be limited by strong competition from other species commencing some weeks after sowing (Hildebrandt \& Schulz 1987). Successful establishment in mixtures is dependent on reducing competition and is more successful where slower establishing grasses are used (Sagar 1962; Tiley \& France 1990).

\section{Soil requirements}

Plantain occurs naturally over a wide range of soil acidity (pH 4.2-7.8) (Troelstra \& Brouwer 1992) and grows well in soils suited to ryegrass and white clover (Voisin 1960). It is found over a wide range of soil textures and organic matter levels, but not on extremely saline or swampy soils (Sawada et al. 1983; Mook et al. 1989; Troelstra \& Brouwer 1992).

Plantain will tolerate a moderate amount of treading and soil compaction but is considerably less tolerant than perennial ryegrass (Voisin 1960; Chappell et al. 1971; Blom 1976; Montacchini \& Siniscalco 1979; Noee \& Blom 1982) or broad leaf plantain (Plantago major).

\section{Soil fertility}

In natural grasslands plantain is a common constituent under conditions of low fertility (Klapp 1949; Olff \& Bakker 1991) owing to its excellent adaptation to lownutrient environments (Troelstra \& Brouwer 1992). In particular plantain is very common on soils low in phosphorus or potassium (Watson \& Nash 1960; Kruijne et al. 1967; Hoveland et al. 1976).

Plantain is responsive to nitrogen applications, promoting leaf number, shoot growth and total biomass but with a more limited effect on root growth (Lambers et al. 1981; Freijsen \& Otten 1987; Blacquiere \& Koetsier 1988; Hirose et al. 1988). However, nitrogen fertiliser applied to mixed grassland swards consistently increases the proportion of grasses and decreases the proportion of plantain and other herbs (Kasper 1976; Romero \& Demanet 1989), and phosphorus or potassium fertiliser has little immediate direct effect on the proportion of plantain (Norman 1956; Voison 1960; Kasper 1976).

The competitive ability of plantain with grasses depends greatly on fertility. Where fertility is low plantain can have a competitive advantage over shallowrooted grasses. Plantain is capable of utilising nutrients from deeper soil layers, and in mixtures plantain has been found to develop a greater proportion of roots at depth than in monocultures. This niche differentiation can provide a yield advantage to mixtures of up to 1.5 times that of the monocultures (Newbery \& Newman 1978; Berendse 1981, 1982, 1983; Troelstra \& Berendse 1982). Where there is competition for nutrients the surface application of fertiliser favours shallow-rooted grasses over the deeper rooted plantain (Berendse 1982).

However, under high fertility the ability to explore greater soil depth is of little competitive advantage to plantain (Berendse 1981). Under these conditions competition for light becomes of greater importance than nutrient uptake parameters in determining the competitiveness of the species. The leaf morphology of grasses then provides them with a competitive advantage for light over plantain (Stulen et al. 1992).

\section{Drought tolerance}

Plantain has drought tolerance more akin to cocksfoot than perennial ryegrass (Malden 1924; Ivins 1952; Mook et al. 1989) with the proportion increasing in mixed swards during drought (Lambert 1963). Plantain also has considerable summer heat tolerance, as indicated by its distribution in sub-tropical grasslands (Sagar \& Harper 1964). The summer yields in Table 1 reflect the drought tolerance.

\section{Pests and diseases}

Of the many insects noted on plantain the most important leaf feeders are the weevils, the gallmidges and the flea beetles (Sagar \& Harper 1964; de Nooij and Mook 1992). Plantain weevil (Gymnetron pascuorum Gyllenhall) has reached very high levels in local seed crops and may require controlling. Plantain has a low acceptability to many slugs and snails (de Nooij \& Mook 1992; Hulme 1996), with chemical extracts deterring the slugs Arion ater, Deroceras reticulatum and Cepaea nemoralis but not Arion rufus or the snail Helix pomatia (Grime et al. 1968; Molgaard 1992). A range of nematodes has been recorded on plantain (de Nooij \& Mook 1992). Plantain has good tolerance to New Zealand grass grub (Costelytra zealandica) and in pastures severely damaged by grass grub it often becomes an important component (Cockayne 1920).

Internationally a wide range of fungal and bacterial diseases has been recorded on plantain (Thornberry \& Anderson 1937; de Nooij \& Mook 1992). Locally the leaf diseases Aschochyta leaf spot, Phoma sp. and Stemphylium sp. have been noted on older leaves and Rhizoctonia sp. Root rot has also been noted on 
occasional plants in second year seed crops (M. Braithwaite pers. comm.).

A number of studies have compared the annual and seasonal yield of plantain with other forage species. The results show clearly that under certain conditions plantain can yield up to $20000 \mathrm{~kg} / \mathrm{ha}$ per year and is as productive as many of our common grasses or clovers (Milton 1938, 1943; Suckling 1960).

A replicated randomised block trial of Ceres Tonic and Grasslands Lancelot plantain was sown on 10 April 1992 at Ceres Research Station near Christchurch under dryland conditions. Plots were cut when the ryegrass reached approximately $2500-3000 \mathrm{~kg} / \mathrm{ha}$, followed by dressings of nitrogen fertiliser. The plantains were compared with a number of well known pasture grasses: Grasslands Nui perennial ryegrass, Grasslands Kara cocksfoot, Grasslands Roa tall fescue, Grasslands Maru phalaris and Grasslands Gala grazing brome.

Table 1 Yields of dryland pure species plots relative to perennial ryegrass (100) over 4 years.

\begin{tabular}{|c|c|c|c|c|c|}
\hline & $\begin{array}{c}\text { Establishment } \\
\text { period ( } 6 \text { months) }\end{array}$ & $\begin{array}{l}\text { Mean } \\
\mathrm{kg} / \mathrm{ha}\end{array}$ & & $\begin{array}{l}\text { Autumn-Winter } \\
\text { Proportion }\end{array}$ & $\begin{array}{l}\text { Summer } \\
\text { Yield }\end{array}$ \\
\hline Perennial ryegrass (kg/ha) & 100 & 9961 & & 26 & 100 \\
\hline \multicolumn{6}{|l|}{ Yields relative to ryegrass } \\
\hline Cocksfoot & 53 & 9862 & (99) & 29 & 126 \\
\hline Tall Fescue & 60 & 9327 & (94) & 25 & 92 \\
\hline Phalaris & 46 & 9254 & (93) & 35 & 71 \\
\hline Grazing Brome & 57 & 10759 & (108) & 36 & 128 \\
\hline Lancelot plantain & 67 & 7582 & $(76)^{\prime}$ & 10 & 105 \\
\hline Tonic plantain & 80 & 8362 & (84) & 21 & 107 \\
\hline LSD $5 \%$ & 18.9 & 961 & $(9.6)$ & 4.6 & 30.1 \\
\hline
\end{tabular}

\section{Forage productivity}

many other factors. Higher proportions of plantain are usually found under low fertility (Klapp 1949; Olff \& Bakker 1991); in swards subject to long grazing or cutting intervals rather than continuous grazing (Tamm 1956; Voisin 1960; Elsasser \& Kunz 1988); under dryland conditions (Lambert 1963) and in swards containing "less aggressive" and slower-establishing companion species (Tiley \& France 1990).

Grasses also have a competitive advantage over plantain owing to their more rapid response following disturbance or management change such as trampling, protection from grazing, fertiliser application and herbicides (Page et al. 1985).

The composition of plantain in mixed swards under sheep grazing was determined in a replicated randomised block trial sown in 15 November 1992 by AgResearch at Lincoln. In this trial Grasslands Lancelot was included in a number of mixtures with common grasses, all sown with Grasslands Prestige white clover. The grasses were Grasslands Roa tall fescue, Grasslands Kara cocksfoot, Grasslands Nui perennial ryegrass (endophyte infected), Grasslands Greenstone hybrid ryegrass (endophyte free) and Grasslands Gala grazing brome. In addition, a further four treatments were included, Gala grazing brome with red clover and white clover, Tonic plantain with white clover, Grasslands Puna chicory with Lancelot plantain and white clover and a herbal ley mix consisting of Lancelot plantain, Puna chicory, Gala grazing brome, Kara cocksfoot, Lotus corniculatus, sheeps burnet and red clover. The sward composition was monitored for over 3 years.

After 3 years plantain contributed between $5 \%$ and $15 \%$ of the sward in mixtures with

Despite being pure swards under cutting, these trials provide a good indication of a number of features of plantain (Table 1). Firstly, it is rapid to establish, almost as fast as ryegrass, yielding better than most alternative grasses in the first year under dryland conditions. Second, Lancelot is winter dormant in this environment while Tonic remains active. The height of Tonic plantain was very similar to that of the perennial ryegrass at each cut but the plot density was lower.

\section{Proportion of plantain in older swards}

The contribution plantain will make to a sward in the longer term is determined by its ability to compete with the other species present. This depends on the specific conditions prevailing, such as fertility level, grazing management, companion pasture species, and persistent grasses (Table 2). However, in plots where Greenstone or red clover had failed to persist the plantain contributed over $30 \%$ to the sward. Perennial ryegrass was more competitive at establishment than other grasses.

Table 2 Composition of plantain mixtures at 3 months, 1 year and 3 years, under sheep grazing at a dryland site at Lincoln.

\begin{tabular}{lccccc}
\hline Dryland & Plantain & Grasses & Legume & Chicory & Other \\
\hline Tonic & $54,67,64$ & & $6,26,15$ & $40,7,21$ \\
Lancelot & $52,56,67$ & & $3,34,13$ & & $45,10,20$ \\
Roa-Lancelot & $47,37,7$ & $18,18,69$ & $8,32,10$ & & $27,13,14$ \\
Kara-Lancelot & $46,34,5$ & $6,9,78$ & $10,40,5$ & $38,17,12$ \\
Gala-Lancelot & $31,23,9$ & $29,19,62$ & $6,32,13$ & & $34,26,16$ \\
Gala-Lancelot-RC & $28,18,36$ & $20,8,23$ & $25,55,13$ & & $27,19,18$ \\
Greenstone-L & $23,26,34$ & $46,17,26$ & $4,39,7$ & & $27,18,33$ \\
Nui-Lancelot & $12,14,11$ & $51,25,65$ & $4,44,10$ & & $33,17,29$ \\
Puna-Lancelot & $22,13,13$ & & $10,32,13$ & $16,49,61$ & $52,6,13$ \\
Herbal ley & $8,5,10$ & $27,12,37$ & $4,37,12$ & $5,35,24$ & $56,11,17$ \\
\hline
\end{tabular}


Similarly, in natural grasslands plantain usually makes up a lower proportion of the sward than the grasses and legumes. It seldom dominates, or contributes more than $20 \%$ to the sward except where the grass or legume is non-competitive.

\section{Palatability}

In mixed pastures plantain is highly palatable to cattle, sheep, deer and horses, and selectively grazed ahead of most legumes and grasses (Milton 1933, 1943; Ivins 1952; Sagar \& Harper 1964; Archer 1971; Clark \& Harris 1985; Bhadresa 1987). This can place plantain at risk of overgrazing, since the proportion of plantain leaf remaining in mixed swards after grazing has been found to be extremely low compared with a range of other species (Derrick et al. 1993).

Reproductive stems of plantain and older mature leaves, however, are much less palatable than fresh leaf material (Ivins 1952) and, as a result, plantain is often able to reseed in pasture (Derrick et al. 1993). Quality can be maintained by grazing before flowering while the stems are still soft and palatable.

\section{Mineral composition}

Many reports have compared the mineral composition of plantain with commonly used grasses and clovers. These show that plantain contains high levels of calcium, magnesium, sodium, phosphorus, zinc, copper and cobalt, at least as high as perennial ryegrass-white clover based pastures and usually higher (Fagan \& Watkins 1932; Thomas \& Thompson 1948; Thomas et al. 1952; Armstrong 1953; Adams \& Elphick 1956; Wohlbier \& Kirchgessner 1957; Bruggemann et al. 1960; Boberfeld \& Buyukburc 1974; Forbes \& Gelman 1981; Holubek \& Jancovic 1989; Tiley \& France 1990; Spatz \& Baumgartner 1990; Wilman \& Riley 1993). The retention of calcium, magnesium and sodium by grazing animals was higher from plantain than from perennial ryegrass, for calcium four times higher (Wilman \& Derrick 1994). This suggests that a small proportion of plantain in the sward could significantly increase calcium retention by animals.

\section{Nutritional value}

Compared with perennial ryegrass, leafy plantain had similar physical breakdown characteristics, a lower proportion of cell wall, less cellulose, less neutral and acid detergent fibre but less crude protein, less water soluble carbohydrate and more lignin. Stems of plantain have more cellulose, more lignin, higher neutral and acid detergent fibre contents and less crude protein than perennial ryegrass stems (Derrick et al. 1993; Isselstein 1993a; Wilman \& Riley 1993; Wilman \& Derrick 1994; Deaker et al. 1994b).

Derrick et al. (1993) reported that with sheep fed ad lib., the daily intake of plantain herbage was slightly higher than that of endophyte-free perennial ryegrass. However, plantain required a greater amount of chewing and rumination activity than perennial ryegrass.

Plantain is considered to make good quality hay but is slower than perennial ryegrass or white clover to dry (Thomas et al. 1952; Turner 1955; Isselstein \& Ridder 1993).

The results of digestibility measurements of plantain herbage vary depending on the method of determination. When measured using the in-vitro cellulose/pepsin method the digestibility has been similar to perennial ryegrass and white clover. However, when the in-vitro rumen-fluid/pepsin method is used the apparent digestibility can be 10-20\% lower (Derrick et al. 1993; Deaker et al. 1994b), although Wilman \& Riley (1993) found that allowing additional time for digestion reduced this effect. Further experiments using rumen fluid from animals previously grazing a range of pasture species led Deaker et al. (1994b) to conclude that plantain herbage slows down the action of rumen microflora but does not permanently impair rumen function. This effect was attributed to the presence of biologically active compounds.

\section{Unique chemical properties}

Plantain contains a number of unique properties for which it has been widely used in traditional medicine around the world. These properties became apparent when Freerksen (1950) and Freerksen \& Boniche (1951) reported antimicrobial properties. Although antimicrobial properties are not unique among plants, it was the only species from 550 surveyed in which the antimicrobial properties were still detectable in rabbit urine samples 8 to 16 hours after feeding.

Further studies have identified the iridoid glucoside aucubin and its derivatives as important biologically active compounds. These have a number of effects, including antimicrobial (Rombouts \& Links 1956; Ishiguro et al. 1982), laxative (Wagner \& Wolff 1976); tissue growth promoters and non-steroidal antiinflammatory (Salas-Auvert et al. 1985); providing liver protection effects (Yang et al. 1983; Chang et al. 1984); weak anti-oxidant (Toda et al. 1985); and stimulation of uric acid excretion (Kato 1946).

Aucubin occurs in plantain at very high levels, up to $3 \%$ of dry matter, depending on the genotype, soil fertility and other factors (Puffe \& Zerr 1989; Fajer et al. 1992; Adler et al. 1995). The levels increase with 
increasing leaf age and during dry summer conditions; even after cutting the levels in detached leaves can increase significantly (Bowers \& Stamp 1992; Stamp \& Bowers 1994, 1996).

The genus Plantago is widely known and used as a source of mucilage, or polysaccharide hydrocolloids (Morton 1977; Franz 1989). Plantain leaves contain approximately $0.8 \%$ of mucilage (Brautigam \& Franz 1985). Mucilage hydrates slowly with water to form a viscous gel regulating movement through the digestive system with its laxative and purgative effects (Duke 1992). Plantago mucilage is used in commercial preparations to control diarrhoea in calves (Verschoor 1987).

$P$. lanceolata also contains the phenylpropanoid glycoside verbascoside (syn: acteoside) at levels up to $9 \%$ of dry matter (Fajer et al. 1992). This compound is also biologically active, having antimicrobial effects (Andary et al. 1982,); antifungal effects (Shoyama et al. 1986); in-vitro antitumour activity (Pettit et al. 1990; Herbert et al. 1991); acting as a strong superoxide anion scavenger and antioxidant (Zhou \& Zheng 1991); and having anti-hypertensive and anti-tremor activity (Andary et al. 1982).

The sugar alcohols sorbitol (syn: $D$-glucitol), and to a lesser extent mannitol, act as the major osmotic regulators in Plantago in contrast to grasses where the amino acid proline performs this role. Sorbitol is commonly present in plantain at $2 \%$ and can accumulate when plants are in drought or saline conditions (Lewis 1984).

Sorbitol has $60-70 \%$ the sweetness of sucrose (Oku 1992) and at the high levels present in plantain has the potential to enhance palatability.

There has been considerable interest in forage plants containing tannins owing to their value in protecting protein in the rumen and to their anthelmintic effects. Plantain contains tannins (Dorfer \& Roselt 1989; Launert 1984). Plantain responds to the vanillin $/ \mathrm{HCl}$ test but gives an unusual slow response, while the butanol- $\mathrm{HCl}$ test (Terrell et al. 1992) indicates that levels of condensed tannins are between 0.4 and $1 \%$. However, in both tests the resultant extracts are of a different colour to that normally obtained and further studies demonstrating that plantain extracts can either precipitate protein or animal studies with PEG (polyethylene glycol) would be required to confirm the presence of condensed tannins (R. Keogh pers. comm.).

\section{Performance of animals grazing plantain}

Liveweight gain trials carried out with plantain have given variable results depending on whether the comparison was pure swards or mixed plantain swards.
In pure swards plantain has generally given liveweight gains equal to or less than endophyte free perennial ryegrass (Derrick et al. 1993; Fraser \& Rowarth 1996), with losses in weight on rank and stemmy swards (Robertson et al. 1995).

In contrast, animal liveweight gains have been improved by the inclusion of plantain in mixed pastures (Thomas et al. 1956). In mixtures with red and white clover the liveweight gain of lambs on a plantain-clover sward was superior to that on a ryegrass-clover, tall fescue-clover and cocksfoot-clover swards but slightly lower than a chicory-clover sward (R. Keogh pers. comm.). In Australia a plantain sward with $10 \%$ clover achieved a liveweight gain of $41 \%$ greater than achieved on a good perennial ryegrass-clover pasture (J. Chin 1996). Unlike the trials with pure swards, this trial was carried out in winter on a leafy plantain sward which had not received nitrogen fertiliser.

The carcass composition of lambs was not affected by grazing plantain. However, they were found to have significantly heavier kidneys with no apparent impairment of renal function (Deaker et al. 1994a), a result attributed to greater water intakes. Greater urine flows are recorded by animals grazing plantain (Wilman \& Derrick 1994), consistent with the diuretic effects of iridoid compounds.

The meat flavour of lambs grown on plantain was no different to those grazing on ryegrass (Fraser et al. 1996).

In some grazing trials of lambs grazing plantain dags and scouring has been less than that in perennial ryegrass, white clover or chicory (J. Deaker pers. comm.).

There has been much interest in anthelmintic properties of plantain. In the laboratory an extract with mild anthelmintic properties has been detected (G. Lane pers. comm.). However, field trials to date have failed to detect any reduction (Robertson et al. 1995; Fraser \& Rowarth 1996, Knight et al. 1996; J. Chin 1996).

\section{Interaction of biologically active chemicals with animal performance}

The antimicrobial compounds in plantain appear capable of interacting with the fermentation process. Deaker (1994b) observed an inhibition of rumen fermentation during herbage digestibility experiments and attributed this to the presence of such compounds.

Similarly, the silage fermentation process is believed to be retarded by antimicrobial compounds. Isselstein (1993a, 1993b) reported that silage $\mathrm{pH}$ values remained over 5 , protein degradation to ammonia was insignificant and there was little lactic or acetic acid produced. However, plantain silage has an agreeable aroma and even after 180 days had not started to deteriorate. 
The ability of some synthetic antibiotics to change microbial activity and protozoal numbers is well known, as is their ability to lower the rate of gas production in the rumen, leading to a reduction in the severity of bloat (Katz et al. 1986) and their effect on mineral metabolism (Chirase et al. 1988). They can promote propionicproducing bacteria, leading to altered volatile fatty acid composition of the rumen with higher propionic to acetic acid ratios (Mir 1989), resulting in improvements to animal productivity and milk composition (Davey 1965). Similar effects have also been reported with some herbal remedies (Randhawa \& Randhawa 1996) and on high starch diets (Forbes \& France 1993).

The supplementation of ruminant diets with Plantago seed husks has been shown to increase the ratio of propionic acid to acetic acid (Mir \& Mir 1994) and initial studies suggest that plantain herbage may have a similar effect (P. Mir pers. comm.).

The presence of antimicrobial compounds capable of affecting the rumen fermentation process is likely to have important implications for rumen efficiency, mineral nutrition of ruminants, animal performance, milk composition, bloat and animal health. Further research will be required to determine their full significance.

\section{ACKNOWLEDGEMENTS}

The author wishes to acknowledge the trial work carried out by staff of AgResearch, Lincoln and for the cooperation of all the researchers undertaking research on plantain.

\section{REFERENCES}

Adams, A.F.R.; Elphick, B.L. 1956. The copper content of some soils and pasture species in Canterbury. New Zealand journal of science and technology $A$ 38: 345-358.

Adler, L.S.; Schmidt, J.; Bowers, M.D. 1995. Genetic variation in defensive chemistry in Plantago lanceolata (Plantaginacea) and its effect on the specialist herbivore Junonia coenia (Nymphalidae). Oecologia 101: 75-85.

Andary, C.; Wylde, R.; Lafitte, R.; Privat, G.; Winternitz, F. 1982. Structures of Verbascoside and Orobanchoside, caffeic acid sugar esters from Orobanche rapum-genistae. Phytochemistry 21: 1123-1127.

Archer, M. 1971. Preliminary studies on the palatability of grasses, legumes and herbs to horses. Veterinary record 89: 236-240.

Armstrong, R.H. 1953. The availability of calcium in three herbs of grassland. Journal of agricultural science 43: 337-342.
Berendse, F. 1981. Competition between plant populations with different rooting depths. II. Pot experiments. Oecologia 48: 334-341.

Berendse, F. 1982. Competition between plant populations with different rooting depths. III. Field experiments. Oecologia 53: 50-55.

Berendse, F. 1983. Interspecific competition and niche differentiation between Plantago lanceolata and Anthoxanthum odoratum in a natural hayfield. Journal of ecology 71: 379-390.

Bhadresa, R. 1987. Rabbit grazing. Studies in a grassland community using faecal analysis and exclosures. Field studies 6: 657-684.

Blacquiere, T.; Koetsier, C. 1988. The response of Plantago lanceolata L. and P. major L. spp. major to nitrate depletion. Plant and soil 107: 197-206.

Blom, C.W.P.M. 1976. Effects of trampling and soil compaction on the occurrence of some Plantago species in coastal sand dunes. I. Soil compaction, soil moisture and seedling emergence. Oecologia 11: 225-241.

Blom, C.W.P.M. 1978: Germination, seedling emergence and establishment of some Plantago species under laboratory and field conditions. Acta botanica neerlandica 27: 257-271.

Bowers, M.D.; Stamp, N.E. 1992. Chemical variation within and between individuals of Plantago lanceolata (Plantaginacea). Journal of chemical ecology 18: 985-995.

Brautigam, M.; Franz, G. 1985. Structural features of Plantago lanceolata mucilage. Planta medica 4: 293-297.

Bruggemann, J.; Bronsch, K.; Drepper, K.; Tiews, J.; Gross, F. 1960. The chemical composition of several species of permanent pastures and the influence of fertilisers on them. Bayerisches Landwirtschaftliches Jahrbuch 37: 273-306.

Chang, I.M.; Yun, H.S.; Kim, Y.S.; Ahn, J.W. 1984. Aucubin: potential antidote for alpha-amanitin poisoning. Clinical toxicology 22: 77-85.

Chappell, H.G.; Ainsworth, J.F.; Cameron, R.A.D.; Redfern, M. 1971. The effect of trampling on a chalk grassland ecosystem. Journal of applied ecology 8: 869-882.

Chin. J. 1996. A preliminary investigation of the effect of 5 pasture species on faecal egg count levels in merino weaner sheep. Unpublished report. 8pp.

Chirase, N.K.; Greene, L.W.; Lunt, D.K.; Baker, J.F.; Knutson, R.E. 1988. Serum and ruminal fluid characteristics of beef cows grazing oat pastures and supplemented with or without lasalocid. Journal of animal science 66: 1746-1754.

Clark, D.A.; Harris, P.S. 1985. Composition of the diet of sheep grazing swards of differing white clover 
content and spatial distribution. New Zealand journal of agricultural research 28: 233-240.

Cockayne, A.H. 1920. The New Zealand grass grub. Some notes on its control. New Zealand journal of agriculture 21: 1-5.

Davey, A.W.F. 1965. Variations in ruminal pH, volatile fatty acid concentration and proportions of the individual acids. Proceedings New Zealand Society of Animal Production 25: 106-116.

de Nooij, M.P.; Mook, J.H. 1992. Interactions with other organisms. pp. 52-68. In: Kuiper, P.J.C.; Bos, M. (eds). Ecological Studies Analysis and Synthesis, Vol. 89. Plantago: a multidisciplinary study. Berlin, Springer-Verlag.

Deaker, J.M.; Hughes, T.P.; Fraser, T.J.; Young, M.J. 1994a. Evidence for the inhibition of rumen microorganisms by plantain (Plantago lanceolata) herbage. Unpublished report.

Deaker, J.M.; Young, M.J.; Fraser, T.J.; Rowarth, J.S. 1994b. Carcass, liver and kidney characteristics of lambs grazing plantain (Plantago lanceolata), chicory (Cichorium intybus), white clover or perennial ryegrass. Proceedings New Zealand Society of Animal Production 54: 197-200.

Derrick, R.W.; Moseley, G.; Wilman, D. 1993. Intake by sheep, and digestibility of chickweed, dandelion, dock, ribwort and spurrey, compared with perennial ryegrass. Journal of agricultural science 120: 5161.

Dorfler, H.; Roselt, G. 1989. The Dictionary of Healing Plants. London and Sydney: Blackford Press.

Duke, J.A. 1992. Handbook of Biologically Active Pytochemicals and their activities. CRC Press Boca Raton, London, Tokyo. 183pp.

Elsasser, M.; Kunz, H.G. 1988. Effects of different fertilisation on permanent grassland comparing conventional and organic farming. pp. 377-381. Proceedings of the 12th General Meeting of the European Grassland Federation, Dublin, Ireland, July 4-7, 1988. Belclare, Tuam, Co. Galway, Irish Republic; Irish Grassland Association.

Fagan, T.W.; Watkins, H.T. 1932. The chemical composition of the miscellaneous herbs of pastures. The Welsh agriculture journal 6: 144-151.

Fajer, E.D.; Bowers, M.D.; Bazzaz, F.A. 1992. The effect of nutrients and enriched $\mathrm{CO}_{2}$ on production of carbon-based allochemicals in Plantago: A test of the Carbon/nutrient balance hypothesis. The American naturalist 140 (4): 707-723.

Forbes, J.C.; Gelman, A.L. 1981. Copper and other minerals in herbage species and varieties on copperdeficient soils. Grass and forage science 36: 2530.

Forbes, J.M.; France, J. 1993. Quantitative aspects of ruminant digestion and metabolism. $\mathrm{CAB}$ International.

Foster, L. 1988. Herbs in pastures. Development and research in Britain, 1850-1984. Biological agriculture and horticulture 5: 97-133.

Fraser, T.L.; Rowarth, J.S. 1996. Legumes, herbs or grass for animal performance. Proceedings of the New Zealand Grassland Conference 58: (this proceedings).

Fraser, T.L.; Scott, S.M.; Deaker, J.M.; Rowarth, J.S. 1996. Pasture species effect on carcass and meat quality. Proceedings of the New Zealand Grassland Conference 58: (this proceedings).

Franz, G. 1989. Polysaccharides in Pharmacy: Current Applications and Future Concepts. Planta medica 55: 493-497.

Freerksen, E. 1950. Zufuhr antibakterieller Wirkstoffe durch Nahrung and Futter. Naturwissenschaften 37: 564-565.

Freerksen, E.; Boniche, R. 1951. Uber antibakterielle Prinzipien in hoheren Pflanzen. Zeitschrift fur die Gesamye Hygiene und Infektionskrankheiten 132: 417-449.

Freijsen, A.H.J.; Otten, H. 1987. A comparison of the responses of two Plantago species to nitrate availability in culture experiments with exponential nutrient addition. Oecologia 74: 389-395.

Grime, J.P.; Macpherson-Stewart, S.F.; Dearman, R.S. 1968. An investigation of leaf palatability using the snail Cepaea nemorlis L. Journal of ecology 56: 405-420.

Herbert, J.M.; Maffrand, J.P.; Taoubi. K.; Augereau, J.M.; Fouraste, I.; Gleye, J. 1991. Verbascoside isolated from Lantana camara, an inhibitor of protein kinase. Canadian journal of natural products (Lloydia) 54 (6): 1595-1600.

Hildebrandt, K.; Schulz, H. 1987. Sowing trials of some selected herbaceous plants. Zeitschrift fur Vegetationstechnik im Landschafts und Sportstattenbau 10: 106-110.

Hirose, T.; Freijsen, A.H.J.; Lambers, H. 1988. Modelling of the responses to nitrogen availability of two Plantago species grown at a range of exponential nutrient addition rates. Plant, cell and environment 11: 827-834.

Holubek, R.; Jancovic, J. 1989. The mineral and nitrogen contents of forbs and legumes. Pol'nohospodarstvo 35: 793-804.

Hoveland, C.S.; Buchanan, G.A.; Harris, M.C. 1976. Response of weeds to soil phosphorus and potassium. Weed science 24: 194-201.

Hulme, P.E. 1996: Herbivores and the performance of grassland plants: a comparison of arthropod, mollusc and rodent herbivory. Journal of ecology 84: 43-51. 
Ishiguro, K.; Yamada, M.; Takagi, S. 1982. Studies on the Iridoid related compounds. 1. On the antimicrobial activity of aucubigenin and certain iridoid aglycones. Yakugaku zasshi 102: 755-759.

Isselstein, J. 1993a. Forage nutritive value and ensilability of some common grassland herbs. Proceedings of the XVII International Grassland Congress: $577-578$.

Isselstein, J. 1993b. Untersuchungen zum futterwert und zur konservierungseignung verbreiteter grunlandkrauter. Mitt. Ges. Pflanzenbauwiss 6: 8992.

Isselstein, J.; Ridder, P. 1993. Untersuchungen zum trocknungsverlauf ausgewahlter grunlandkrauter unter kontrollierten bedingungen. Das Wirtschaftseigene Futter 39: 136-145.

Ivins, J.D. 1952. The relative palatability of herbage plants. Journal of the British Grassland Society 7: 43-54.

Kasper, J. 1976. The effect of fertilisation rates on the development and chemical composition of common herbs in perennial grass stands. Rostlinna vyroba 22: 639-650.

Kato, Y. 1946. Mechanism of uric acid excretion stimulation of aucubin. Folia pharmacol. Japon 42: 27-40.

Katz, M.P.; Nagaraja, T.G.; Fina, L.R. 1986. Ruminal changes in monensin and lasolocid-fed cattle grazing bloat provocative alfalfa pastures. Journal of animal science 63: 1246-1257.

Klapp, E. 1949. Permanent pastures of west and south Germany. A sociological and ecological study. Zeitschrift fur Acker und Pflanzenbau 91: 346-373.

Knight, T.L.; Fraser, T.L.; Rowarth, J.S. 1996. Species effect on internal parasites. Proceedings of the New Zealand Grassland Conference 58: (this proceedings).

Kruijne, A.A.; de Cries, D.M.; Mooi, H. 1967. Contribution to the ecology of the Dutch grassland plants. Agricultural Research Report 696. Pudoc, Wageningen (in Dutch, with English summary).

Lambers, H.; Posthumus, F.; Stulen, I.; Lanting, L.; van Dijk, S.; Hofstra, R. 1981. Energy metabolism of Plantago lanceolata as dependent on the supply of mineral nutrients. Physiologia plantarum 51: 8592.

Lambert, J. 1963. Effect of the 1962 spring drought on the behaviour of some grass swards in the Ardennes. Revue agriculture (Brux.) 16: 1593-1604.

Launert, E. 1984. The Country Life Guide to Edible and Medicinal plants of Britain and Northern Europe. 288pp. England: Country Life Books.

Lewis, D.H. 1984. Storage carbohydrates in vascular plants. Distribution, physiology and metabolism.
Society for Experimental Biology, Seminar series 19. Cambridge: Cambridge University Press.

Malden, W.J. 1924. Grassland Farming, Pastures and Leys. London: Ernest Benn.

Milton, W.E.J. 1933. The palatability of the selfestablishing species contributing to different types of grassland. Empire journal of experimental agriculture 1: 347-360.

Milton, W.E. 1938. The yield of certain miscellaneous herbs compared with grasses when grown in drills. Welsh Journal of Agriculture 14: 196-202.

Milton, W.E.J. 1943. The yield of ribwort plantain (ribgrass) when sown in pure plots and with grass and clover species. Welsh journal of agriculture 17: 109-116.

Mir, P.S.; Mir, Z. 1994. Psyllium husk as a potential feed supplement for ruminants. Proceedings of the Society for Nutritional Physiology 3: 198.

Mir, Z. 1989. Monensin, chlortetracycline and tylosin effects on performance and digestion in lambs fed a ground alfalfa diet. Canadian journal of animal science 69: 505-508.

Molgaard, P. 1992. Polymorphism for caffeic acid esters in populations of Plantago major ssp pleisperma. pp. 192-203. In: Kuiper, P.J.C.; Bos, M. (eds). Ecological Studies Analysis and Synthesis, Vol. 89. Plantago: a multidisciplinary study. Berlin: SpringerVerlag.

Montacchini, F.; Siniscalco, C. 1979. The effects of foot traffic on vegetation and soils of city park turfs. Annali della Facolta di Scienze Agrarie della Universita degli Studi di Torino 12: 365-385.

Mook, J.H.; Haeck. J.; van der Toorn, J.; van Tienderen, P.H. 1989. Comparative demography of Plantago I. Observations on eight populations of Plantago lanceolata. Acta Botanica Neerlandica 38: 67-78.

Morton, J.F. 1977. Major Medicinal Plants. Botany, Culture and Uses. Springfield, USA: Charles C. Thomas.

Newbery, D. McC.; Newman, E.I. 1978. Competition between grassland plants of different initial sizes. Oecologia 33: 361-380.

Noee, R.; Blom, C.W.P.M. 1982. Occurrence of three Plantago species in coastal dune grasslands in relation to the pore volume of the soil. Journal of applied ecology 19: 177-182.

Norman, M.J.T. 1956. Intervals of superphosphate application to downland permanent pasture. Journal of agricultural science 47: 157-171.

Oku, T. 1992. Dietary fibre and new sugars. pp. 159170. In: Baba, S.; Akerele, O.; Kawaguchi, Y. (eds). Natural Resources and Human Health. Plants of medicinal and nutritional value. Amsterdam, London, New York, Tokyo: Elsevier. 
Olff, H.; Bakker, J.P. 1991. Long-term dynamics of standing crop and species composition after the cessation of fertiliser application to mown grassland. Journal of applied ecology 28: 1040-1052.

Page, R.R.; da Vinha, S.G.; Agnew, A.D.Q. 1985. The reaction of some sand-dune plant species to experimentally imposed environmental change: a reductionist approach to stability. Vegetatio 61: 105114.

Pettit, G.R.; Numata, A.; Takemura, T.; Ode, R.H.; Narula, A.S.; Schmidt, J.M.; Cragg, G.M.; Pase, C.P. 1990. Antineplastic agents, 107. Isolation of acteoside and isoacteoside from Castilleja linariaefolia. Journal of natural products 53: 456458.

Puffe, D.; Zerr, W. 1989. The content of various secondary plant products in widespread weeds in grassland with particular regard to high lying areas. Eichhof Berichte 11: 127pp.

Randhawa, C.S; Randawa, S.S. 1996. herbal remedies stimulate rumen function. Feed mix 4: 31-34.

Robertson, H.A.; Niezen, J.H.; Waghorn, G.C.; Charleston, W.A.G.; Jinlong, M. 1995. The effect of six herbages on liveweight gain, wool growth and faecal egg count of parasitised ewe lambs. New Zealand Society of Animal Production 55: 199-201.

Rombouts, J.E.; Links, J. 1956. The chemical nature of the antibacterial substance present in Aucuba japonica. Experientia 12: 78-80.

Romero, Y.O.; Demanet, F.R. 1989. Improvement of naturalised pastures in the dry coastal and interior sectors of Region IX. Agricultura tecnica 49: 2430.

Sagar, G.R. 1962. The effect of S23 ryegrass on the establishment and growth of three species of plantains Plantago lanceolata, P. major, P. media. Annals of applied biology 50: 352.

Sagar, G.R.; Harper, J.L. 1964. Biological flora of the British Isles. Plantago major L., P. media L. and $P$. lanceolata L. Journal of ecology 58: 189-221.

Salas Auvert, R.; Avila Mayor, A.; Avila, A. 1985. Treatment of cutaneous equine habronemiasis with a beta-glycoside, aucubigenin. Equine practice 7: $22-25,28$.

Sawada, S.; Sugai, M.; Hirmori, H. 1983. Water status and physical properties of soil and vegetation at habitats of some Plantago species. Japanese journal of ecology 33 (2): 149-160.

Shoyama, Y.; Matsumoto, M.; Nishioka, I. 1986. Four caffeoyl glycosides from callus tissue of Rehmannia glutinosa. Phytochemistry 25: 1633-1636.

Spatz, G.; Baumgartner, A. 1990. Evaluation of some grassland herbs as forage plants. Wirtschaftseigene Futter 36: 79-91.
Stamp, N.E.; Bowers, M.D. 1994. Effect of cages, plant age and the mechanical clipping on plantain chemistry. Oecologia 99: 66-71.

Stamp, N.E.; Bowers, M.D. 1996. Effect of temperature and leaf age on growth versus moulting time of a generalist caterpillar fed plantain (Plantago lanceolata). Ecological entomology 19: 199-206.

Stewart, C.G. 1991. Coccidiosis of sheep. Sheep in Natal. Extension report, Department of Agricultural Development, Republic of South Africa. 2 pp.

Stulen, I.; Freijsen, A.H.J.; Blacquiere, T. 1992. Acquisition and Utilization of Nitrogen. pp. 138147. In: Kuiper, P.J.C.; Bos, M. (eds). Ecological Studies Analysis and Synthesis, Vol. 89. Plantago: a multidisciplinary study. Berlin: Springer-Verlag.

Suckling, F.E.T. 1960. Productivity of pasture species on hill country. New Zealand journal of agricultural research 3: 579-591.

Tamm, C.O. 1956. Composition of vegetation in grazed and mown sections of a former hay meadow. Oikos 7: 144-157 and 273-292.

Terrell, T.H.; Rowan, A.M.; Douglas, G.B.; Barry, T.N. 1992. Determination of extractable and bound condensed tannin concentrations in forage plants, protein concentrate meals and cereal grains. Journal of the science of food and agriculture 58: 321-329.

Thomas, B.; Rogerson, A.; Armstrong, R.H. 1956. The influence of mineral-rich herbs on the yield and nutritive value of swards. 1 Dry matter production and composition under pasture condition. Journal of the British Grassland Society 11: 10-15.

Thomas, B.; Thompson, A. 1948. The ash content of some grasses and herbs on the Palace Leas hay plots at Cockle Park. The empire journal of experimental agriculture 16: 221-230.

Thomas, B.; Thompson, A.; Oyenuga, V.A.; Armstrong, R.H. 1952. The ash constituents of some herbage plants at different stages of maturity. The empire journal of experimental agriculture 20: 10-22.

Thornberry, H.H.; Anderson, W.H. 1937. Some bacterial diseases of plants in Illinois. Phytopathology 27: 946-949.

Tiley, G.E.D.; France, J. 1990. An agronomic evaluation of forage herbs in grassland. pp. 163-166. In: Soilgrassland-animal relationships. Proceedings of the 13th General Meeting of the European Grassland Federation, Banska Bystrica, Czechoslovakia, June 25-29, 1990. Volume 2.

Toda, S.; Miyase, T.; Arichi, H.; Tanizawa, H.; Takino, Y. 1985. Natural antioxidants. II. Antioxidative components isolated from seeds of Plantago asiatica L. Chemical and pharmaceutical bulletin 33: 12701273.

Troelstra, S.R.; Berendse, F. 1982. Root CEC 
determinations to establish root biomasses of two plant species grown in mixtures. Plant and soil 64: 277-281.

Troelstra, S.R.; Brouwer, R. 1992. Mineral nutrient concentrations in the soil and in the plant. pp. 122137. In: Kuiper, P.J.C.; Bos, M. (eds). Ecological Studies Analysis and Synthesis, Vol. 89. Plantago: a multidisciplinary study. Berlin: Springer-Verlag.

Turner, F.N. 1955. Fertility Pastures. London: Faber and Faber.

Verschoor, J. 1987. Control of gastro-intestinal malfunction using specific mucopolysaccharides and enzymes. British Cattle Veterinary Association Proceedings for 1985-86: 99-105.

Voisin, A. 1960. Better Grassland Sward, Ecology, Botany and Management. London: Crosby Lockwood.

von Boberfeld, W.O.; Buyukburc, U. 1974. Effect of water-table level on the content of major and trace elements in some grassland plants. Wirtschaftseigene Futter 20: 135-159.

Wagner, H.; Wolff, P. 1976. New natural products and plant drugs with pharmacological, Biological or therapeutical activity. Proceedings of the First International Congress on Medicinal Plant
Research, section A, held at University of Munich, Germany 1976: 137-176.

Watson, S.J.; Nash, M.J. 1960. The conservation of grass and forage crops. London: Oliver and Boyd. 2nd Edition.

Wilman, D.; Derrick, R.W. 1994. Concentration and availability to sheep of $\mathrm{N}, \mathrm{P}, \mathrm{K}, \mathrm{Ca}, \mathrm{Mg}$ and $\mathrm{Na}$ in chickweed, dandelion, dock, ribwort and spurrey, compared with perennial ryegrass. Journal of agricultural science 122: 217-223.

Wilman, D.; Riley, J.A. 1993. Potential nutritive value of a wide range of grassland species. Journal of agricultural science 120: 43-49.

Wohlbier, W.; Kirchgessner, M. 1957. Der Gehalt von einzelnen Grasern, Leguminosen und Krautern an Mengen- und Spurenelementen. Landwirtschaftliche Forschung 10: 240-251.

Yang, K.H.; Kwon, T.J.; Choe, S.Y.; Yun, H.S.; Chang, I.M. 1983. Protective effect of Aucuba japonica against Carbon Tetrachloride-induced liver damage in rats. Drugs and chemical toxicology 6: 429-441.

Zhou, Y.C.; Zheng, R.L. 1991. Phenolic compounds and an analog as superoxide anion scavengers and antioxidants. Biochemical pharmacology 42: 11771180 . 